\title{
Antigenic and Molecular Homology of the Ferric Enterobactin Receptor Protein of Escherichia coli
}

\author{
By HENRIK CHART* AND ELWYN GRIFFITHS \\ National Institute for Biological Standards and Control, Holly Hill, London NW3 6RB, UK
}

(Received 13 November 1984)

\begin{abstract}
The ferric enterobactin receptor protein $(81 \mathrm{kDal})$ of Escherichia coli 0111 was purified by preparative sodium dodecyl sulphate-polyacrylamide gel electrophoresis and used to raise polyclonal antiserum in rabbits. This antiserum was used in conjunction with the immunoblot technique to examine the degree of antigenic homology of the ferric enterobactin receptor protein among 17 pathogenic and laboratory strains of $E$. coli. Both the molecular weight and the antigenic properties of the enterobactin receptor were highly conserved. However, the laboratory strain $\mathrm{C}$ and a pathogenic enteroinvasive strain, E. coli O164, were unusual in not producing the $81 \mathrm{kDal}$ protein. The antiserum also recognized an $81 \mathrm{kDal}$ protein from ironrestricted Salmonella typhimurium and an $83 \mathrm{kDal}$ protein from iron-restricted Klebsiella pneumoniae.
\end{abstract}

\section{INTRODUCTION}

The availability of iron in the tissues of the mammalian host is severely restricted. Most of the iron is found intracellularly as ferritin, haemosiderin or haem and that which is extracellular in body fluids is attached to the iron-binding glycoproteins transferrin and lactoferrin. Since these proteins have a high association constant for iron and are normally only partly saturated, they ensure that little free iron is available to invading micro-organisms. Consequently, pathogenic bacteria have evolved high-affinity uptake systems which can successfully compete with these iron-binding glycoproteins for essential ferric ions (Finkelstein et al., 1983; Griffiths, 1983). When Escherichia coli is placed in an iron-limited environment, several outer membrane proteins are derepressed and at least one high-affinity iron-chelating agent (siderophore) is synthesized (Neilands, 1982). One of the induced proteins, the $81 \mathrm{kDal}$ product of the fep gene, is the receptor for ferric iron complexed with the siderophore enterobactin. Enterobactinmediated iron uptake is of particular interest in the study of bacterial pathogenicity, since both the chelator and its outer membrane receptor are produced by $E$. coli growing in vivo during infection (Griffiths \& Humphreys, 1980; Griffiths et al., 1983).

Recent results from this laboratory have shown that normal human adult sera contain naturally occurring IgG antibodies which react with the outer membrane proteins of $E$. coli (Griffiths, 1983; Griffiths et al., 1985). Interestingly, the major antigenic components recognized by these antibodies were the ompA proteins and the iron-regulated outer membrane proteins, including the enterobactin receptor. The possibility that antibodies to the enterobactin receptor might interfere with iron uptake and inhibit bacterial growth is currently being investigated, as is the degree of antigenic homology of the $81 \mathrm{kDal}$ protein in different strains of $E$. coli. In the present study we isolated the ferric enterobactin receptor protein from $E$. coli $\mathrm{O} 111$ by preparative polyacrylamide gel electrophoresis and used antiserum raised to this preparation to assess the antigenic homology of the $81 \mathrm{kDal}$ protein of 17 strains of $E$. coli. Our results suggest that the molecular weight and antigenic properties of the enterobactin receptor protein are highly conserved and that this correlation extends to other members of the Enterobacteriaceae. 
Table 1. Strains of E. coli

Strain

1. $\mathrm{K} 12$

2. $W 3110$

3. $\mathrm{W}$

4. $C$

5. MRE 600

6. $\mathrm{O} 128 \mathrm{~K} 67 \mathrm{H} 2$

7. $\mathrm{O} 111 \mathrm{~K} 58 \mathrm{H} 2$

8. 015

9. $078 \mathrm{~K} 80$

10. $018 \mathrm{~K} 1 \mathrm{H} 7$

11. $\mathrm{O} 2 \mathrm{Hl}$

12. $\mathrm{O} 128 \mathrm{H} 49$

13. $\mathrm{O} 159 \mathrm{H} 20$

14. $\mathrm{O} 78 \mathrm{H} 11 \mathrm{~K} 2$

15. O149 K91 H10

16. $0164 \mathrm{H}^{-}$

17. $\mathrm{O} 124 \mathrm{H} 30$
Designation

Laboratory strain

Laboratory strain

Laboratory strain

Laboratory strain; ATCC 3121

Laboratory strain

Enteropathogenic

Enteropathogenic

Enteropathogenic

Extraintestinal; $\mathrm{ColV}^{+}$

Extraintestinal; $\mathrm{ColV}^{+}$

Extraintestinal

Enterotoxigenic; $\mathrm{ST}^{-} \mathrm{LT}^{+}$

Enterotoxigenic; $\mathrm{ST}^{+} \mathrm{LT}^{-}$
Enterotoxigenic; $\mathbf{S T}^{+} \mathbf{L T}^{+} \mathrm{CFA} / \mathrm{I}^{+}$

Enterotoxigenic

Enteroinvasive

Enteroinvasive
Source

This laboratory

C. Yanofsky, Stanford University, Calif., USA

M. Buck, Biochemistry Dept, University of

California, Berkeley, USA

This laboratory

J. Dolby, Clinical Research Centre, Harrow, UK

This laboratory

J. Dolby

H. Williams Smith, Houghton Research Station,

Huntingdon, UK

This laboratory

Central Public Health Laboratory, Colindale, London, UK

This laboratory

Central Public Health Laboratory, Colindale,

London, UK

\section{METHODS}

Bacteria. Strains of E. coli used in this study are listed in Table 1. Isolates of Salmonella typhimurium LT2 and Klebsiella pneumoniae were obtained from stocks held at The National Institute for Medical Research, Mill Hill, London, UK.

Bacterial surface antigens. Lipopolysaccharide (LPS) prepared from E. coli $0111 \mathrm{~K} 58 \mathrm{H} 2$ by the methods of Fitzgerald \& Rogers (1980) was kindly donated by Dr H. J. Rogers.

Media and culture conditions. Strains were stored at $-70^{\circ} \mathrm{C}$ in brain-heart infusion broth (Difco) containing $10 \%(\mathrm{v} / \mathrm{v})$ glycerol. Iron-restricted growth was achieved by growing the bacteria in trypticase soy broth (BBL) containing either ovotransferrin as described previously (Griffiths \& Humphreys, 1978), or $200 \mu \mathrm{M}-\alpha, \alpha^{\prime}$-dipyridyl (Sigma). Iron-replete organisms were grown in trypticase soy broth alone.

Isolation of outer membranes. Bacterial outer membranes were isolated as described by Chart \& Trust (1983) with the exception that the cells were disrupted by sonication $\left(150 \mathrm{~W}, 5 \mathrm{~min}, 0^{\circ} \mathrm{C}\right)$. The protease inhibitor benzamidine (Sigma) was used at a concentration of $10 \mathrm{mM}$ (Hollifield et al., 1978). ${ }^{125}$ I-labelled proteins were obtained by radio-iodinating membrane proteins exposed on the surface of intact $E$. coli $\mathrm{O} 18$ as described by Griffiths $e t$ al. (1983).

Electrophoresis. Outer membrane protein samples were prepared for sodium dodecyl sulphate-polyacrylamide gel electrophoresis (SDS-PAGE) as described by Chart \& Trust (1983). Protein bands were detected with Coomassie Brilliant Blue R (Chart \& Trust, 1983) or by the silver staining method of Wray et al. (1981). LPS was detected in gels by the procedure of Tsai \& Frasch (1982).

Immunoblotting. SDS-PAGE profiles were transferred by electroblotting to nitrocellulose papers and reacted with sera as described by Stevenson \& Griffiths (1985). Rabbit antibody was detected by using ${ }^{125}$ I-labelled goat anti-rabbit antiserum (Miles Laboratories).

Rabbit antiserum. Antiserum was raised in a female Dutch rabbit. Isolated receptor protein $(30 \mu \mathrm{g})$ was injected subcutaneously in Freund's complete adjuvant at multiple sites. A second injection in incomplete adjuvant was administered intramuscularly 3 weeks later. After $10 \mathrm{~d}$, the rabbit was bled from the marginal ear vein and the serum was separated after clot formation.

\section{RESULTS}

\section{Purification of the $81 \mathrm{kDal}$ protein}

E. coli O111 was chosen as a source of ferric enterobactin receptor protein since this strain produced particularly large amounts of the protein under iron-restricted conditions. For protein isolation, outer membranes were prepared from E. coli O111 grown in 1 litre volumes of trypticase soy broth containing ovotransferrin. Since the protease inhibitor benzamidine retards proteolytic degradation of the $81 \mathrm{kDal}$ protein of $E$. coli K12 (Hollifield et al., 1978) it was added to all reagents used in the protein isolation procedure. 
Preparative gel electrophoresis was used to isolate the $81 \mathrm{kDal}$ protein. Samples $(1 \mathrm{mg})$ of outer membrane protein preparation were applied to a single well extending the whole width of the gel. After electrophoresis, gels were stained briefly in Coomassie Blue until the $81 \mathrm{kDal}$ band was visible $(5 \mathrm{~min})$. The entire band was then cut out and macerated by passage through a $10 \mathrm{ml}$ plastic syringe. Protein was eluted from the macerate with $125 \mathrm{~mm}-\mathrm{Tris} / \mathrm{HCl} \mathrm{pH} 6.8$ containing $0.5 \%(\mathrm{w} / \mathrm{v}) \operatorname{SDS}\left(2 \mathrm{~d}, 4^{\circ} \mathrm{C}\right)$ and precipitated from the eluate with acetone/triethylamine/glacial acetic acid $\left(90: 5: 5\right.$, by vol.) at $-20^{\circ} \mathrm{C}$. The precipitates were collected by centrifugation $\left(4000 \mathrm{~g}, 20 \mathrm{~min}, 4^{\circ} \mathrm{C}\right)$ in conical glass tubes.

SDS-PAGE of the protein preparations showed only a single $81 \mathrm{kDal}$ band after staining with Coomassie Blue; a trace of an additional $74 \mathrm{kDal}$ protein was also visible on silver staining (results not shown). Staining for LPS by the method of Tsai \& Frasch (1982) failed to detect Opolysaccharide in the gel profiles. This protein preparation was used to raise antibodies in rabbits.

\section{Specificity of antibodies to the $81 \mathrm{kDal}$ protein}

The growth of $E$. coli $\mathrm{O} 111$ in broth containing the iron chelator $\alpha, \alpha^{\prime}$-dipyridyl resulted in the expression of large amounts of the $81 \mathrm{kDal}$ protein. Since this chelator was more economical and convenient to use than ovotransferrin it was used to bring about the expression of the ironregulated outer membrane proteins in the strains tested. The SDS-PAGE profiles of outer membrane proteins isolated from different strains of $E$. coli grown in the presence of $\alpha, \alpha^{\prime}-$ dipyridyl are shown in Fig. 1 (a). By using the $81 \mathrm{kDal}$ protein band of strain $\mathrm{K} 12$ as a reference (lane 1), it can be seen that all strains except $\mathrm{C}$ and $\mathrm{O} 164$ have an $81 \mathrm{kDal}$ band (arrowed). As noted previously, however (Griffiths et al., 1983), there was considerable variation between strains with respect to the number and quantity of iron-regulated proteins expressed.

The electrophoresed proteins were transferred from gels onto nitrocellulose paper and reacted with the antiserum raised to the purified $81 \mathrm{kDal}$ protein. Fig. $1(b)$ shows that an $81 \mathrm{kDal}$ band (arrowed) was recognized in all strains except $\mathrm{C}$ and $\mathrm{O} 164$. In addition, the antiserum produced a weak reaction with an antigen (arrowed) having a relative mobility equivalent to a protein of $24 \mathrm{kDal}$. This antigen was present in all strains tested, as well as in iron-replete $E$. coli $\mathrm{O} 111$ (results not shown). In order to show that the antiserum was reacting with the $81 \mathrm{kDal}$ protein, the outer membrane proteins of $E$. coli $\mathrm{O} 18$ were extrinsically labelled with ${ }^{125} \mathrm{I}$ and the labelled preparation used as markers in SDS-PAGE. An unlabelled outer membrane protein preparation from iron-restricted E. coli 0111 was electrophoresed in a gel adjacent to the ${ }^{125} \mathrm{I}$-labelled proteins and the separated proteins were transferred onto a nitrocellulose sheet. This was cut into two between the lanes, using pinking shears to produce a serrated edge, and the paper carrying the unlabelled proteins was reacted in the usual way with the antiserum raised to the $81 \mathrm{kDal}$ protein of $E$. coli O111. Both the immunoblot and the nitrocellulose paper carrying the separated ${ }^{125} \mathrm{I}$-labelled proteins were finally placed onto X-ray film and aligned using the serrated edges. In this way an outer-membrane protein profile was produced on the film alongside and aligned with the antiserum blot. The results showed that the antiserum was indeed recognizing the $81 \mathrm{kDal}$ protein (Fig. $2 a$ ). This antiserum failed to detect an $81 \mathrm{kDal}$ band in the outer membrane protein profile of iron replete $E$. coli 0111 (not shown).

Two bacterial species other than $E$. coli were also examined to ascertain the degree of antigenic conservation of the ferric-enterobactin receptor protein. The results in Fig. $2(b)$ clearly show that the anti-receptor antibodies recognized an $81 \mathrm{kDal}$ band in the outer membrane protein profile of $S$. typhimurium and an $83 \mathrm{kDal}$ band in that from $K$. pneumoniae. These were the only bands detected.

Interestingly, the antiserum also reacted with what appeared to be LPS in E. coli O111, O18 and to a lesser extent W3110 (Fig. $1 b$ ). To investigate this observation, the antiserum was reacted with purified LPS from homologous $E$. coli O111. An enzyme-linked immunosorbent assay demonstrated that the anti-receptor antiserum did indeed contain antibodies to LPS. The SDS-PAGE profile of LPS from $E$. coli O111, stained for LPS by the silver staining technique of Tsai \& Frasch (1982) (Fig. $3 a$ ), closely resembled the outer membrane components recognized 

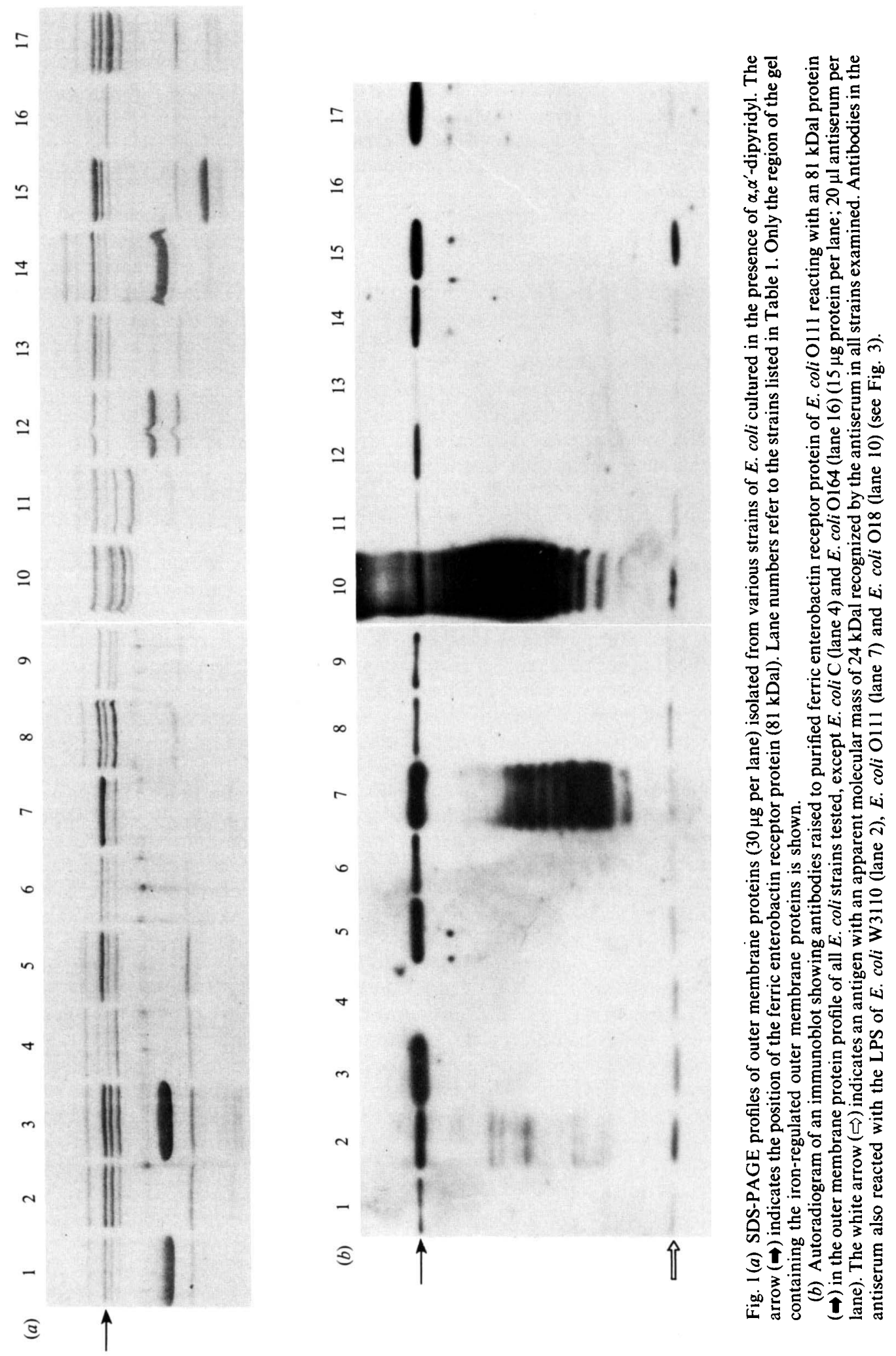
1

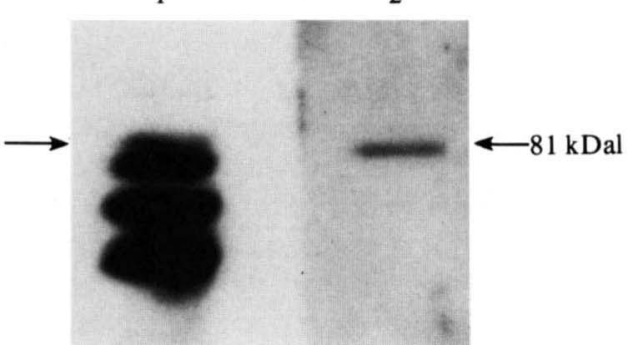

(a)

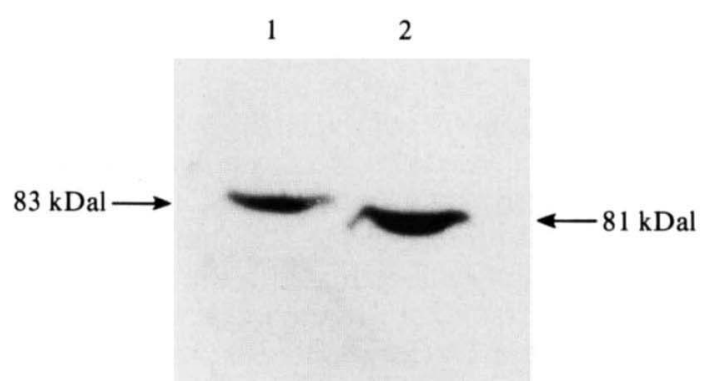

(b)

Fig. 2(a) Immunoblot of the separated iron-regulated outer membrane proteins of $E$. coli $O 111(15 \mu \mathrm{g}$ per lane) reacted with the antiserum $(20 \mu \mathrm{l}$ per lane) raised to the $81 \mathrm{kDal}$ protein of $E$. coli $\mathrm{O} 111$; in this experiment antibodies to LPS were absorbed by addition of homologous LPS (lane 2) (see also Fig. $3 b$ ). Lane 1 carried ${ }^{125} \mathrm{I}$-labelled outer membrane proteins of iron-restricted $E$. coli $\mathrm{O} 18$. The radiolabelled proteins were electrophoresed at the same time as and transferred to the nitrocellulose paper along with the unlabelled proteins run in lane 2 . The immunoblot and the nitrocellulose paper carrying the ${ }^{125} \mathrm{I}$ labelled proteins were aligned as described in the text, before being placed on the X-ray film. Only the region of the gel containing the iron-regulated outer membrane proteins is shown.

(b) Immunoblot of the iron-regulated outer membrane proteins (15 $\mu \mathrm{g}$ per lane) isolated from $K$. pneumoniae and $S$. typhimurium reacted with the antiserum $(20 \mu \mathrm{l}$ per lane) raised to the $81 \mathrm{kDal}$ protein; the bacteria were grown in the presence of $\alpha, \alpha^{\prime}$-dipyridyl. The antibodies recognized an $83 \mathrm{kDal}$ protein in $K$. pneumoniae (lane 1) and an $81 \mathrm{kDal}$ protein in $S$. typhimurium (lane 2). Only the region of the gel containing the iron-regulated outer membrane proteins is shown.

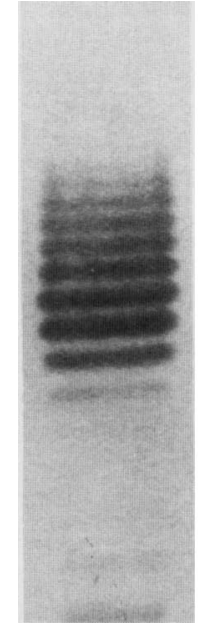

(a)

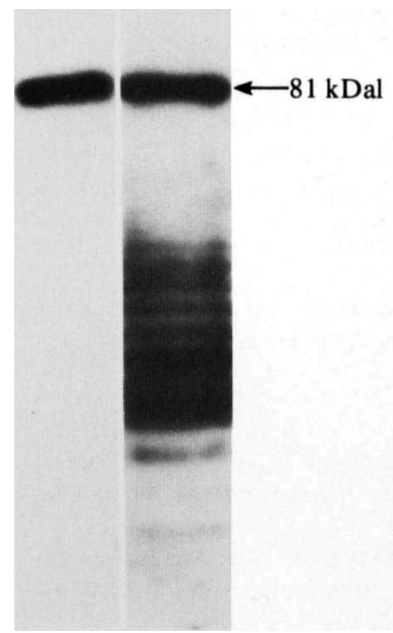

(b)

Fig. 3(a) SDS-PAGE profile of LPS from E. coli O111. Only the higher molecular weight region of the gel is shown. (b) Immunoblot of the outer membrane proteins isolated from $E$. coli 0111 cultured in the presence of $\alpha, \alpha^{\prime}$-dipyridyl and reacted with antibodies to the ferric enterobactin receptor protein. Lane 1 was reacted with antiserum absorbed with purified LPS from $E$. coli O111; no reaction with LPS can be seen. In contrast, lane 2 shows that the nonabsorbed serum recognized both the $81 \mathrm{kDal}$ receptor protein and LPS. (See also Fig. $1 b$, lane 7). Only the higher molecular weight region of the gel is shown.

by the antiserum in the above three strains. Adding purified $E$. coli O111 LPS to the antireceptor antiserum absorbed the anti-LPS antibodies, leaving the remaining antibodies to react with the enterobactin receptor (Fig. $3 b$ ) and the antigen with an apparent molecular mass of $24 \mathrm{kDal}$ (results not shown). 


\section{DISCUSSION}

The results reported in this paper show that both the molecular weight and at least some antigenic properties of the ferric-enterobactin receptor protein are conserved within the strains of $E$. coli examined. Antigenic similarities between the receptor proteins of several $E$. coli strains would help to explain why normal human sera from a range of sources contained antibodies to the $81 \mathrm{kDal}$ protein of the test strains (Griffiths, 1983; Griffiths et al., 1985). The degree to which antibodies reacting with the iron-regulated outer membrane proteins, and specifically with the ferric enterobactin receptor, might be involved in host defence is unknown.

Preparative gel electrophoresis proved to be a successful way of isolating the $81 \mathrm{kDal}$ protein. However, the presence in the antiserum of antibodies reacting with LPS suggests that there was an extremely low level of contaminating LPS present in the purified protein used for immunization, even though silver staining of SDS-PAGE gels failed to detect it. Examination of LPS profiles in SDS-PAGE gels showed that the $81 \mathrm{kDal}$ protein and some of the high molecular weight LPS co-migrate.

The recognition by the antiserum of an additional antigen with a molecular mass equivalent to a protein of $24 \mathrm{kDal}$ indicated that antibodies to the $81 \mathrm{kDal}$ protein were either cross-reacting with common epitopes on another outer membrane component or that this material was a proteolytic breakdown product of the $81 \mathrm{kDal}$ protein. The latter seems unlikely since this antigen was present in strains which did not have a ferric enterobactin receptor protein $(E$. coli $\mathrm{C}$ and O164) and also in iron-replete E. coli O111. Furthermore, it was not present in the profile of $S$. typhimurium which contained an $81 \mathrm{kDal}$ protein.

Antibodies to the ferric enterobactin receptor of $E$. coli $\mathrm{O} 111$ also cross-reacted with the ironregulated outer membrane proteins of two other bacterial species. The recognition of an $81 \mathrm{kDal}$ band in the outer membrane protein profile of iron-restricted $S$. typhimurium was not surprising since this organism can both synthesize and utilize enterobactin (Neilands, 1982). However, the reaction of the anti-receptor antibodies with an $83 \mathrm{kDal}$ protein from iron-restricted $K$. pneumoniae was unexpected. Williams et al. (1984) reported that under iron restriction, $K$. aerogenes produced an $83 \mathrm{kDal}$ protein but not an $81 \mathrm{kDal}$ protein, although this organism could utilize ferric enterobactin as an iron source. From the reaction that we observed, it would seem that in $K$. pneumoniae and $K$. aerogenes the enterobactin receptor protein has a molecular mass of $83 \mathrm{kDal}$ and not $81 \mathrm{kDal}$.

We thank Pauline Stevenson for helpful advice and discussion, and the World Health Organization and Medical Research Council for financial support.

\section{REFERENCES}

Chart, H. \& Trust, T. J. (1983). Acquisition of iron by Aeromonas salmonicida. Journal of Bacteriology 156, $758-764$.

Finkelstein, R. A., Sciortino, C. V. \& Mcintosh, M. A. (1983). Role of iron in microbe-host interactions. Reviews of Infectious Diseases 5, S759-777.

Fitzgerald, S. P. \& Rogers, H. J. (1980). Bacteriostatic effect of serum: role of antibody to lipopolysaccharide. Infection and Immunity 27, 302-308.

GrIFFITHS, E. (1983). Adaptation and multiplication of bacteria in host tissues. Philosophical Transactions of the Royal Society B303, 85-96.

Griffiths, E. \& HUMPHREYS, J. (1978). Alterations in tRNAs containing 2-methylthio- $N^{6}-\left(\Delta^{2}\right.$-isopentenyl)-adenosine during growth of enteropathogenic Escherichia coli in the presence of iron binding proteins. European Journal of Biochemistry 82, 503513.

Griffiths, E. \& HumPhreys, J. (1980). Isolation of enterochelin from the peritoneal washings of guineapigs lethally infected with Escherichia coli. Infection and Immunity 28, 286-289.
Griffiths, E., Stevenson, P. \& Joyce, P. (1983). Pathogenic Escherichia coli express new outer membrane proteins when growing in vivo. FEMS Microbiology Letters 16, 95-99.

Griffiths, E., Stevenson, P., Thorpe, R. \& Chart, H. (1985). Naturally occurring antibodies in human sera that react with the iron regulated outer membrane proteins of Escherichia coli. Infection and Immunity 47, 808-813.

Hollifield, W. C., Fiss, E. H. \& Neilands, J. B. (1978). Modification of a ferric enterobactin receptor protein from the outer membrane of Escherichia coli. Biochemical and Biophysical Research Communications 83, 739-746.

NeIlands, J. B. (1982). Microbial envelope proteins related to iron. Annual Review of Microbiology 36, 285-309.

Stevenson, P. \& Griffiths, E. (1985). Detection of antibodies and antigens by immunoblotting. In The Virulence of Escherichia coli. Edited by M. Sussman (Society for General Microbiology Special Publication no. 13). London: Academic Press. 
TSAI, C. M. \& Frasch, C. E. (1982). A sensitive silver stain for detecting lipopolysaccharide in polyacrylamide gels. Analytical Biochemistry 119, 115-119.

Williams, P., Brown, M. R. W. \& Lambert, P. A. (1984). Effect of iron deprivation on the production of siderophores and outer membrane proteins in
Klebsiella aerogenes. Journal of General Microbiology 130, 2357-2365.

Wray, W., Boulikas, T., Wray, P. \& Hancock, A. (1981). Silver staining of proteins in polyacrylamide gels. Analytical Biochemistry 118, 197-203. 